Original Research

\title{
Monitoring the Changes in the Microbial Dynamics of Calcareous Soil with the Amendment of Stabilized and Dried Sewage Sludge in Mediterranean Region of Turkey
}

\author{
Ismail Emrah Tavali', Sule Orman²*, Aylin Ozgur², Ilker $\mathbf{U z}^{2}$, Saira Sulaman² \\ ${ }^{1}$ Department of Medicinal and Aromatic Plants, Gazipaşa M. Rahmi Büyükballı Vocational School, \\ Alanya Alaaddin Keykubat University, Antalya, Turkey \\ ${ }^{2}$ Department of Soil Science and Plant Nutrition, Faculty of Agriculture, Akdeniz University, Antalya, Turkey
}

Received: 6 February 2021

Accepted: 8 April 2021

\begin{abstract}
Since sewage sludge contains plant nutrients and organic matter, it has a potential to act as a soil conditioner for maintainig soil fertility in crop production. In this experiment, different quantities of stabilized and dried sewage sludge (SS) were applied to a calcareous soil. Treatments used for this study were $0 \mathrm{t} \mathrm{ha}^{-1}$ (SS0/control), $20 \mathrm{t} \mathrm{ha}^{-1}$ (SS2), $40 \mathrm{t} \mathrm{ha}^{-1}$ (SS4), $60 \mathrm{t} \mathrm{ha}^{-1}$ (SS6), $80 \mathrm{t} \mathrm{ha}^{-1}$ (SS8) respectively. This study was aimed to investigate the changes in soil microbial dynamics by application of sewage sludge during growing crop conditions. A field experiment was done by using randomized blocks design and every treatment was replicated four times. Soil samples were collected at three different periods of plant growth. Number of bacteria (heterotrophic aerobic mesophilic) and changes in soil enzyme activities (nitrification, nitrate reductase, urease, alkaline phosphatase, $\beta$-glycosidase) were examined. According to the results, it is clear that the sludge applications have stimulating effect both on soil enzyme activities (excluding nitrate reductase) and the number of bacteria. With the application of sewage sludge soil microbial dynamics significantly increased (nitrification $=41.72 \%$, urease $=35.14 \%$, alkaline phosphatase $=43.29 \%, \beta$-glycosidase $=59.64 \%$, number of bacteria $=91.66 \%$ ) as compared to the control.
\end{abstract}

Keywords: number of bacteria, organic waste, soil conditioner, soil enzymes, soil fertility

*e-mail: suleorman@akdeniz.edu.tr 


\section{Introduction}

There are many factors that differentiate the physical, chemical and biological properties of the sewage sludges resulting from wastewater treatment, primarily the source of wastewater, seasonal changes, the infrastructure of the wastewater treatment facility and the type of drying process [1]. Although the characteristics of the sludge vary depending on the source and treatment technology, it was reported that they are rich in organic matter, nitrogen $(\mathrm{N})$ and phosphorous (P) and may be useful when they are placed in the soil under control [2]. It was reported that the plant nutritional value of the sludge is similar to manure and compost and contains all the elements necessary for the development of plants [3]. The sludge, which occurs continuously and in significant amounts due to the increase of urbanization and the human population, has the potential to be used in crop production by applying it to the soil by scientific and environmentalist methods. Heavy metal contents of the sewage sludges are one of the factors limiting the use of soil. However, not only the properties of the sludge but also the characteristics of the soil is important. The heavy metal contents and other risk factors of sewage sludges arising from the domestic waste are generally low. It was reported that the risks that may occur in terms of heavy metal accumulation are minimized by applying stabilized and dried the sewage sludge to soils with high $\mathrm{pH}$, lime and clay content [4].

The sewage sludges can increase the microbial activity of soils due to their rich organic matter and nutrient content [5]. One of the most important features in soil biology is soil microbial dynamics.
Soil microbial dynamics generally covers the number, diversity and activities of the microorganisms in soil ecology. In addition, it is closely related to the behavior of microorganisms both among themselves and against other living creatures depending on the changing conditions (food, $\mathrm{O}_{2}$, temperature, humidity, etc.) in this environment [6]. Soil enzymes are one of the factors that affect microbial dynamics the most. Soil enzymes are biochemical agents and direct many series of reactions that catalyze nutrients in the soil. These reactions can be carried out in living or dead organisms or by extracellular enzymes. Extracellular enzymes may be free or bound to soil colloids [7]. Enzymes that pass from plant residues to soil as a result of vegetative production lose their activity by being broken down immediately because they are not resistant to environmental conditions. Therefore, it is accepted that the origin of active enzymes in the soil are microorganisms [8]. In this study, the changes occurred in the microbial dynamics of the calcareous soil were monitored during the cultivation of silage maize by applying the stabilized and dried sewage sludge to the soil.

\section{Materials and Methods}

\section{The Experiment Soil and Climate}

This study was carried out as a field experiment at the Research and Application Farm of Agriculture Faculty $\left(36^{\circ} 53^{\prime} 54.50^{\prime \prime} \mathrm{N}\right.$ and $30^{\circ} 38^{\prime} 19^{\prime \prime} \mathrm{E}, 31 \mathrm{~m}$ above sea level) located within the campus area of Akdeniz University in Antalya, Turkey (Fig. 1). The experiment

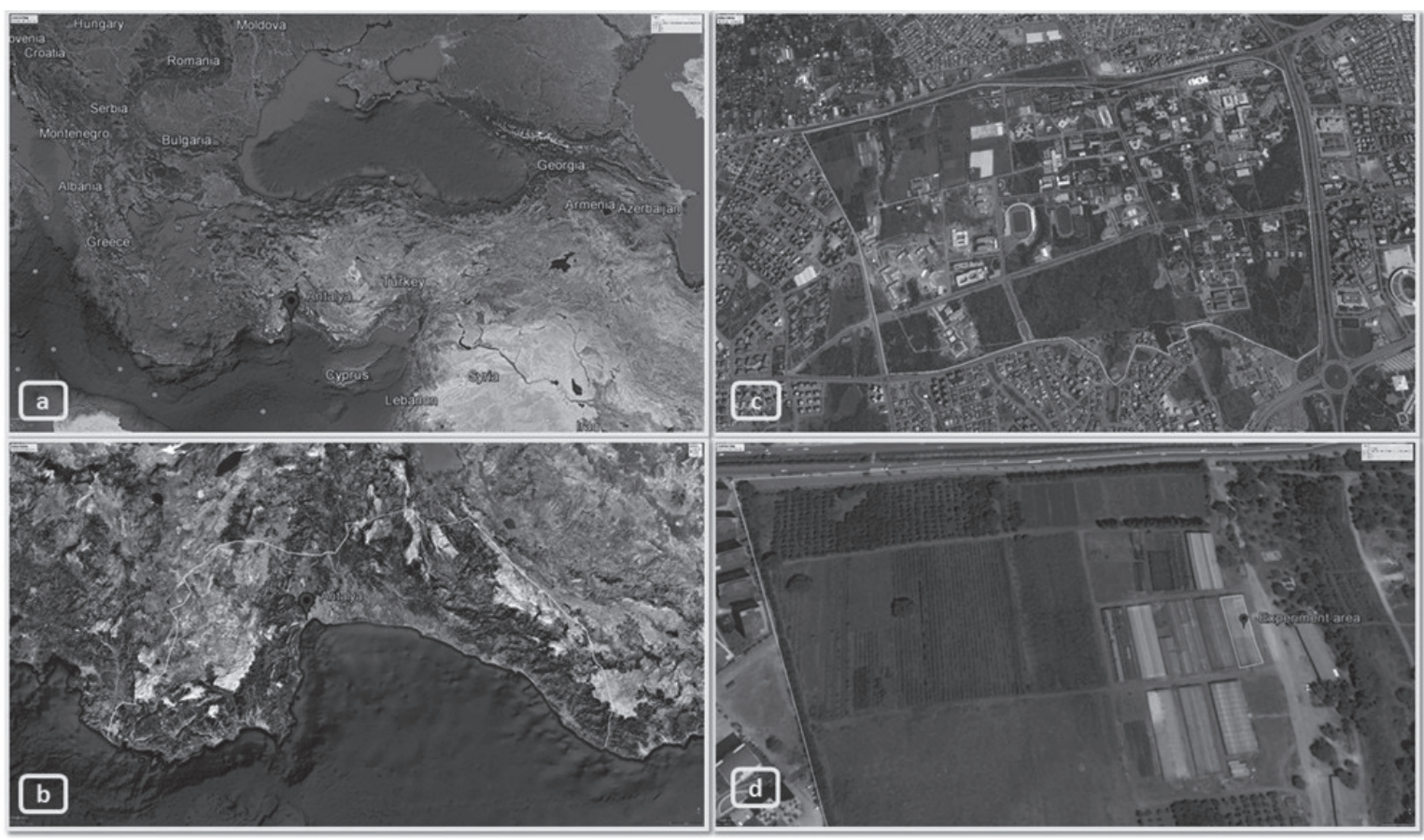

Fig. 1. The location of study area (a: Turkey, b: Antalya, c: Akdeniz University Campus, d: Experiment area). 
soil is called entisol according to international soil taxonomy. According to the morphological profile examination, the whole profile of the soil is clay textured and there is a deeply pronounced lime movement within the profile, and the amount of lime increases with the depth. The texture of the experiment soil is clay loam. It was determined that the soil reaction was slightly alkaline $(\mathrm{pH} 7.06)$, high in lime (43\%) and poor in humus (organic matter: 1.39\%). The area where the experiment is conducted has a semi-arid Mediterranean climate. According to the climate data obtained, the average temperature is $26.7^{\circ} \mathrm{C}$, the highest temperature is $32.5^{\circ} \mathrm{C}$, the lowest temperature is $21^{\circ} \mathrm{C}$ during the months of the experiment (June, July, August and September). In addition, it was determined that the average amount of precipitation in these months was $7.3 \mathrm{~kg} / \mathrm{m}^{2}$

\section{The Sewage Sludge}

The stabilized and dried sewage sludge used in the experiment was obtained from Hurma Waste Water
Treatment Facility in Antalya, Turkey $\left(36^{\circ} 50^{\prime} 08^{\prime \prime} \mathrm{N}\right.$ and $\left.30^{\circ} 36^{\prime} 15^{\prime \prime} \mathrm{E}\right)$. It was determined that the sludge reaction was slightly acid ( $\mathrm{pH} 6.42)$, rich in total $\mathrm{N}(4.9 \%)$ and also rich in humus (organic matter: 74\%). However, it was reported that the heavy metal concentrations of the sewage sludge obtained from this treatment facility are below the sewage sludge heavy metal limit values in the European Union (86/278/EEC) and the "Soil Pollution Control" regulation in Turkey [1]. The results of the analysis of the soil in the area where the experiment was established and the sludge used in the experiment are shown in Table 1.

\section{Experiment Management}

The study was planned according to the random blocks experiment design with 4 replications. Tillage was made suitable for crop production by cultivation, leveling and weed cleaning in the experiment area. Then, 20 plots of $6 \mathrm{~m}^{2}(1.5 \times 4)$ were created. The stabilized and dried sewage sludge (SS) was applied to the soil homogeneously at levels of $0 \mathrm{t} \mathrm{ha}^{-1}$

Table 1. Some chemical properties of the sewage sludge and experiment soil.

\begin{tabular}{|c|c|c|c|c|c|c|c|}
\hline & \multirow[t]{2}{*}{ Parameter } & \multirow[t]{2}{*}{$\begin{array}{l}\text { Sewage } \\
\text { sludge }\end{array}$} & \multirow[t]{2}{*}{ Soil } & \multicolumn{2}{|c|}{$\begin{array}{c}\text { Certificated } \\
\text { Clay loam soil material } \\
\text { (RTC CRM052) }\end{array}$} & \multicolumn{2}{|c|}{$\begin{array}{c}\text { Certificated } \\
\text { Sewage sludge material } \\
\text { (CRM029-50G) }\end{array}$} \\
\hline & & & & Reference & Value & Reference & Value \\
\hline & $\mathrm{pH}$ & 6.42 & 7.06 & - & - & - & - \\
\hline & $\mathrm{EC} \mathrm{ds} \mathrm{m^{-1 }}$ & 5.44 & 0.44 & - & - & - & - \\
\hline & $\% \mathrm{CaCO}_{3}$ & - & 43 & - & - & - & - \\
\hline & Texture & - & Clay loam & - & - & - & - \\
\hline & Drganic matter & 74 & 1.39 & - & - & - & - \\
\hline \multirow{14}{*}{ Total } & $\% \mathrm{~N}$ & 4.9 & 0.13 & $3.97 \pm 0.562$ & 3.42 & $3.26 \pm 0.56$ & 4.58 \\
\hline & P mg kg-1 & 16144 & 118 & $168 \pm 30.7$ & 102.67 & $2.11 \pm 0.26$ & 1.51 \\
\hline & $\mathrm{K} \mathrm{mg} \mathrm{kg}^{-1}$ & 4484 & 8226 & $2390 \pm 76.2$ & 1858.40 & $3540 \pm 290$ & 3604 \\
\hline & Ca mg kg-1 & 61400 & 53512 & $2860 \pm 118$ & 1680.97 & $51600 \pm 1650$ & 55620 \\
\hline & $\mathrm{Mg} \mathrm{mg} \mathrm{kg}^{-1}$ & 6506 & 4267 & $1690 \pm 74.8$ & 1593.10 & $10400 \pm 395$ & 10428 \\
\hline & $\mathrm{Na}_{\mathrm{mg} \mathrm{kg}}{ }^{-1}$ & 1496 & 474.4 & $319 \pm 17.2$ & 156.78 & $1310 \pm 384$ & 1091 \\
\hline & $\mathrm{Fe} \mathrm{mg} \mathrm{kg}^{-1}$ & 5772 & 2619 & $14700 \pm 632$ & 13920 & $23200 \pm 1460$ & 20396 \\
\hline & $\mathrm{Zn} \mathrm{mg} \mathrm{kg}^{-1}$ & 2400 & 50 & $94.3 \pm 2.93$ & 86.41 & $833 \pm 40$ & 784.6 \\
\hline & Mn mg kg ${ }^{-1}$ & 382.6 & 466.6 & $217 \pm 11.8$ & 348.16 & $756 \pm 56.8$ & 663 \\
\hline & $\mathrm{Cu} \mathrm{mg} \mathrm{kg}^{-1}$ & 142.8 & 8 & $56.5 \pm 1.60$ & 49.60 & $716 \pm 37.7$ & 658.20 \\
\hline & Ni mg kg-1 & 126 & 48.9 & $50.8 \pm 1.42$ & 59.82 & $373 \pm 24.8$ & 316 \\
\hline & $\mathrm{Cr}_{\mathrm{mg} \mathrm{kg}}{ }^{-1}$ & 51.3 & 35.5 & $57.8 \pm 1.98$ & 72.00 & $129 \pm 3.69$ & 116.80 \\
\hline & $\mathrm{Pb} \mathrm{mg} \mathrm{kg}^{-1}$ & 23.6 & $<$ D.L.* & $82.9 \pm 2.52$ & 91.10 & $192 \pm 13.9$ & 197.6 \\
\hline & $\mathrm{Cd} \mathrm{mg} \mathrm{kg}^{-1}$ & 1.08 & 0.8 & $43 \pm 1.16$ & 34.85 & $142 \pm 7.54$ & 147.20 \\
\hline
\end{tabular}

* $<$ D.L. Below the detection limits of the device (for Pb D.L. $<0.03 \mathrm{mg} \mathrm{kg}^{-1}$ ) 
(control-SS0), 20 tha $^{-1}$ (SS2), 40 tha $^{-1}$ (SS4), 60 tha $^{-1}$ (SS6), $80 \mathrm{t} \mathrm{ha}^{-1}(\mathrm{SS} 8)$ as reported by Orman et al. [1]. Later, a drip irrigation system was installed in each plot and the plot soils were mixed with the sewage sludge by watering evenly and left for incubation for 3 weeks.

"Burak", a registered silage maize (Zea mays L.) variety of the Western Mediterranean Agriculture Research Institute-BATEM (Antalya, Turkey), was used as plant material. After incubation period, maize seeds were planted for approximately $5 \mathrm{~cm}$ soil depth, two for each dripper, $60 \mathrm{~cm}$ between rows and $20 \mathrm{~cm}$ above the rows as reported by Vieria et al. [5]. During the growth of the plant, all agronomic practices (equal irrigation, weed cleaning, hoeing, etc.) were carried out and silage maize, which completed the 100-day growing period, were harvested.

\section{Sampling and Analysis}

To determine the initial soil properties of the experiment area, first soil sample was taken from 0-30 $\mathrm{cm}$ depth. The soil sample was analyzed by sieving it through a $2 \mathrm{~mm}$ sieve (10 mesh) after making the air dry. In order to determine the effects of the sludge applied to the soil on soil microbial dynamics, samples were taken from a depth of $0-30 \mathrm{~cm}$ at different times and moist soil samples were used in the analysis. Soil samples were taken from each plot when the incubation period was completed (I). In addition, soil samples were also taken when the plants reached the period of stub (II) and in the harvest (III).

The following analysis was carried out in the sludge. Organic matter content was determined according to oven-drying method [9]. $\mathrm{pH}$ and EC values were determined by the pH-EC meter (WTW-400) [10]. Total nitrogen $(\mathrm{N})$ determination was done according to the modified Kjeldahl method (Gerhardt Vapodest 300) [11]. For the total phosphorus (P), potassium (K), calcium $(\mathrm{Ca})$, magnesium $(\mathrm{Mg})$, sodium $(\mathrm{Na})$, iron $(\mathrm{Fe})$, zinc $(\mathrm{Zn})$, manganese $(\mathrm{Mn})$, copper $(\mathrm{Cu})$, lead $(\mathrm{Pb})$, cadmium $(\mathrm{Cd})$, chromium $(\mathrm{Cr})$, nickel $(\mathrm{Ni})$ analysis, filters were obtained by wet decomposition method (digiblock Labtech ED 36S) [12]. Then, the total concentrations of the elements mentioned in these filters were determined by ICP-OES (Perkin Elmer 7100DV). The chemical analyzes made in the first soil sample are as follows: Soil texture (Hamilton Beach-CS) [13], lime (Eijkelkamp C-08.53) [14] and organic matter [15]. pH, $\mathrm{EC}$ and total $\mathrm{N}, \mathrm{P}, \mathrm{K}, \mathrm{Ca}, \mathrm{Mg}, \mathrm{Na}, \mathrm{Fe}, \mathrm{Zn}, \mathrm{Mn}, \mathrm{Cu}, \mathrm{Pb}$, $\mathrm{Cd}, \mathrm{Cr}$, Ni were determined with the same methods used for the sludge.

The biological analyzes performed in replicate soil samples are as follows: nitrification activity [16], nitrate reductase activity [17], urease activity [18], alkaline phosphatase activity [19], $\beta$-glycosidase activity [20]. Sample readings on all enzyme activities were performed on a spectrophotometer (Perkin Elmer Lambda 25 UV-VIS). In addition, total number of aerobic mesophilic bacteria was determined by using dilution plate count method [21]. Soil samples taken for biological analysis were brought to the laboratory quickly and safely. These were kept under suitable conditions $\left(+4^{\circ} \mathrm{C}\right)$ for analysis and data were expressed on the basis of the oven-dry weight of the soil.

\section{Statistical Analysis}

The results obtained from the laboratory analysis were evaluated statistically using SPSS 17.0 package program. In this context, the significance of the data (treatments, time-bound change and interaction of these) were determined at 5\% level with repeated measure ANOVA (rANOVA). In addition, significant results were graded by Duncan's multiple comparison test [22].

\section{Results and Discussion}

\section{Nitrification Activity}

Statistical analysis results including the sludge applications and interactions of time-bound factors are given in Table 2. Accordingly, SS6 (2.14 $\mu \mathrm{g} \mathrm{NO} \mathrm{N}_{2}^{-}$ $\left.-\mathrm{N} \mathrm{g}^{-1} \mathrm{dw} \mathrm{h}^{-1}\right)$ and SS8 (2.11 $\left.\mu \mathrm{g} \mathrm{NO}_{2}^{-}-\mathrm{N} \mathrm{g}^{-1} \mathrm{dw} \mathrm{h}^{-1}\right)$ increased nitrification activity of the soil more than other applications and control. In terms of timebound of nitrification activity, it was determined that the value measured in the second sampling time was the highest activity value (Fig. 2). Nitrification is closely related to nitrogen enrichment in the soil. It is especially studied as an important indicator in the conversion of organic nitrogen in the soil to nitrite and nitrate forms [23]. In this study, the nitrification of the soil showed an increase between the sampling times. It can be stated that the suitability of factors such as climate, soil temperature, microbial diversity and soil $\mathrm{pH}$ are responsible for this change in the nitrification. It is known that nitrification is closely related to soil chemical and biological properties [24]. In addition, the properties of the sludge such as organic matter (74\%) and nutrient content (total $\mathrm{N} \mathrm{4.9 \% )} \mathrm{are} \mathrm{thought}$ to promote microorganisms responsible for nitrification activity. As a matter of fact, organic fertilizer and olive wastewater were reported to have similar effects on soil $[25,26]$. Thus, the enzymatic properties of soils are positively affected by the addition of organic waste. In particular, organic materials containing nutrients such as $\mathrm{N}$ and $\mathrm{P}$, which have low $\mathrm{C} \mathrm{N}$ ratio and high levels in their chemical composition, have a stimulating effect on microorganisms [2].

\section{Nitrate Reductase Activity}

The effects of applications on soil nitrate reductase activity were found statistically insignificant (Table 2). On the other hand, in terms of the time-bound change of the activity, just as in nitrification, it was seen that the measured value was the highest in the second sampling 
Table 2. Effects of applications on soil enzyme activities and number of bacteria.

\begin{tabular}{|c|c|c|c|c|c|c|}
\hline Treatment & $\begin{array}{l}\text { Nitrification } \\
\left(\mu \mathrm{g} \mathrm{NO}_{2}^{-}-\mathrm{N} \mathrm{g}^{-1}\right. \\
\left.\mathrm{dw} \mathrm{h}^{-1}\right)\end{array}$ & $\begin{array}{l}\text { Nitrate reductase } \\
\left(\mu \mathrm{g} \mathrm{NO}_{2}^{-}-\mathrm{N} \mathrm{g}^{-1}\right. \\
\left.\mathrm{dw} \mathrm{h}^{-1}\right)\end{array}$ & $\begin{array}{c}\text { Urease } \\
\left(\mu \mathrm{g} \mathrm{NH}_{4}^{+}-\mathrm{N} \mathrm{g}^{-1}\right. \\
\left.\mathrm{dw} \mathrm{h}^{-1}\right)\end{array}$ & $\begin{array}{c}\text { Alkaline } \\
\text { phosphatase } \\
\left(\mu \mathrm{g} \mathrm{PNP} \mathrm{g}^{-1} \mathrm{dw} \mathrm{h}^{-1}\right)\end{array}$ & $\begin{array}{c}\beta \text {-glucosidase } \\
\left(\begin{array}{c}\mu \mathrm{g} \mathrm{PNG} \mathrm{g}^{-1} \mathrm{dw} \\
\left.\mathrm{h}^{-1}\right)\end{array}\right.\end{array}$ & $\begin{array}{c}\text { Number } \\
\text { of bacteria } \\
\left(10^{6} \mathrm{cfu} \mathrm{g}^{-1} \mathrm{dw}\right)\end{array}$ \\
\hline SS0 & $1.51 \mathrm{c}^{1}$ & 1.99 & $41.52 \mathrm{c}$ & $41.16 \mathrm{~d}$ & $20.12 c$ & $1.2 \mathrm{c}$ \\
\hline SS2 & $1.86 \mathrm{~b}$ & 2.04 & $49.51 b c$ & $49.12 \mathrm{c}$ & $28.17 b$ & $2.1 \mathrm{ab}$ \\
\hline SS4 & $1.97 \mathrm{ab}$ & 2.18 & $52.12 b$ & $53.17 \mathrm{~b}$ & $30.28 \mathrm{ab}$ & $2.1 \mathrm{ab}$ \\
\hline SS6 & $2.14 \mathrm{a}$ & 2.23 & $56.11 \mathrm{a}$ & $58.98 \mathrm{a}$ & $32.12 \mathrm{a}$ & $2.3 \mathrm{a}$ \\
\hline SS8 & $2.11 \mathrm{a}$ & 2.14 & $49.10 b c$ & $52.82 \mathrm{~b}$ & $31.98 \mathrm{a}$ & $1.8 \mathrm{~b}$ \\
\hline \multicolumn{7}{|c|}{ rANOVA (LSD 5\%) } \\
\hline Time $(\mathrm{T})$ & $1.23 *$ & $9.12 * *$ & $87.11 * * * 2$ & $29.69 * * *$ & $11.51^{* * 3}$ & $1.29 * 4$ \\
\hline $\begin{array}{l}\text { Treatment } \\
\text { (T) }\end{array}$ & $1.28 * 4$ & NS & $1.03 *$ & $1.28^{*}$ & $10.47 * *$ & $1.54 *$ \\
\hline $\mathrm{T} \times \mathrm{T}$ & NS & NS & $2.02 *$ & $2.03 *$ & $1.53 *$ & $\mathrm{NS}^{5}$ \\
\hline
\end{tabular}

${ }^{1}$ Means in the same column followed by the same letter are not significantly different at the $5 \%$ level according to Duncan's multiple range test

$2 * * * \mathrm{p}<0.001$

$3 * * \mathrm{p}<0.01$

$4 * \mathrm{p}<0.05$

${ }^{5}$ NS: Not significant
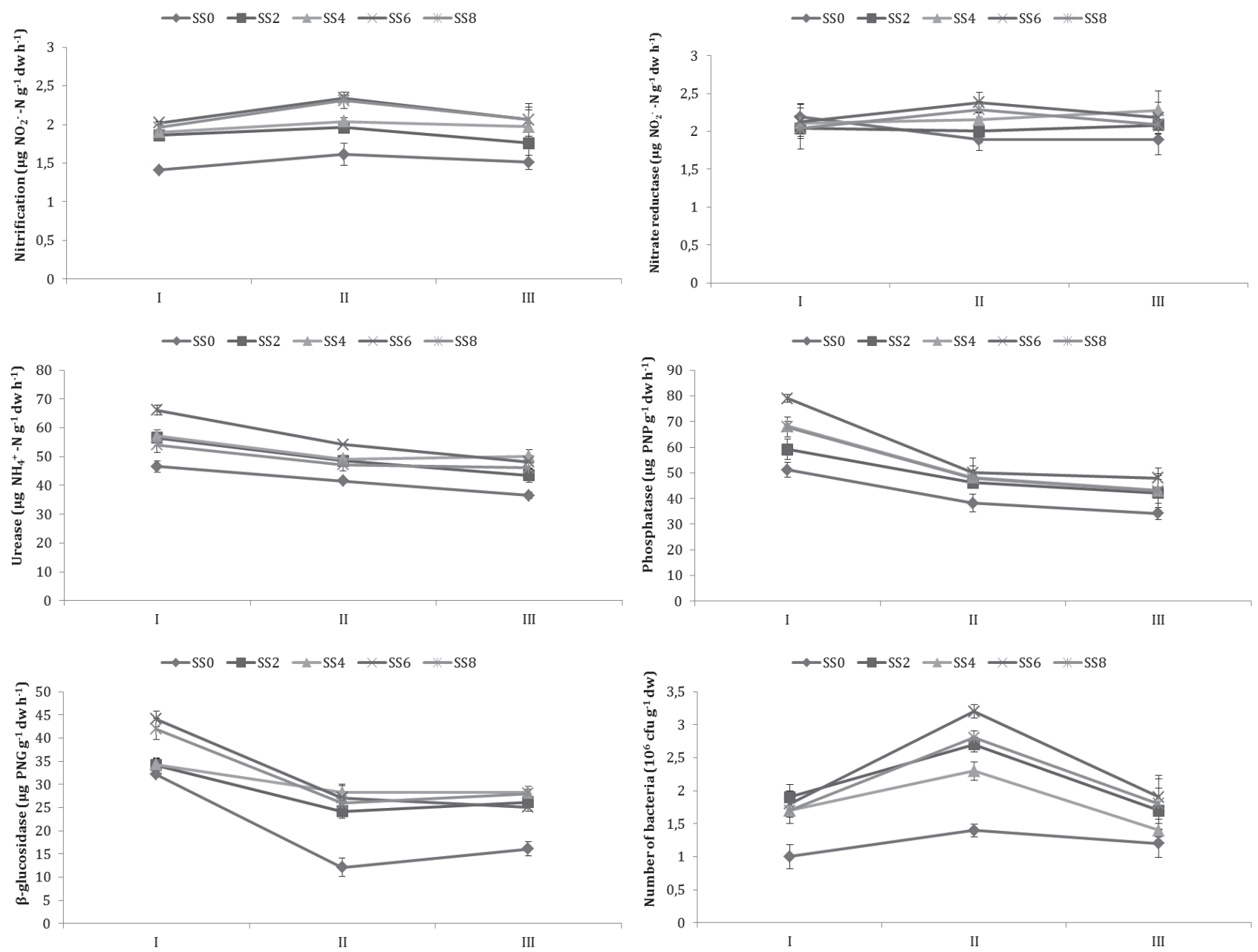

Fig. 2. Changes in enzyme activities and number of bacteria in soils during the growth season (I, II, III) with sewage sludge (SS) applied at the rates of 20,40,60,80 tha-1 and control (SS0) treatments. Error bars represent standard errors based on four replicates. 
time (Fig. 2). Among the most important components of soil fertility, besides available plant nutrients (such as nitrogen), the amount of organic matter and the diversity, number and activity of microorganisms are also included [6]. One of the phases that are in the nitrogen cycle and are most interested in their results is denitrification. The conversion of mineral nitrogen released in the soil as a result of microorganism activities to atmospheric nitrogen under non- $\mathrm{O}_{2}$ conditions is expressed as denitrification. However, it is known that nitrogen loss through soil denitrification causes both the impoverishment of the soils and the negative effects of the gas balance of the atmosphere [27]. Nitrate reductase is involved in the process of denirification. Nitrogen present in the structure of this enzyme, rather than molecular $\mathrm{O}_{2}$, acts as a terminal electron acceptor by bacteria and this is irreversible once NO is formed [28]. It was found that the nitrate reductase activity of the soil showed complex changes with a decreasing trend between the sampling times. It is assumed that this is due to the variability of factors such as nutrient content, $\mathrm{O}_{2}$, temperature, $\mathrm{pH}$, moisture and microbial diversity in the soil during plant growth. Similarly, soil nitrate reductase activity and nitrous oxide gas amount were reported to fluctuate due to changing conditions $[29,30]$.

\section{Urease Activity}

SS6 (56.11 $\left.\mu \mathrm{g} \mathrm{NH}_{4}^{+}-\mathrm{N} \mathrm{g} \mathrm{g}^{-1} \mathrm{dw} \mathrm{h} \mathrm{h}^{-1}\right)$ increased urease activity more than control and all other applications (Table 2). However, it was determined that the enzyme activity, which was measured high in the first sampling time, decreased gradually in the following sampling times (Fig. 2). It states that soil enzymes are responsible for the decomposition of organic materials in the soil, as well as the input of organic material into the soil can increase these enzymes and this increase may differ significantly depending on the type of organic material [31]. The urease enzyme, which is effective in the separation of urea and ammonium, nitrogenous compounds in the soil, is an important extracellular soil enzyme that takes part in the nitrogen cycle. This enzyme constitutes more than $63 \%$ of all enzyme activities in the soil and is in close relationship with soil microbial activity increase [32]. The urease enzyme is held in various ways by inorganic structures in colloidal tissue such as clay and does not lose its activity in the soil most of the time [5]. The urease activity also increases due to the increase of microorganism activity in the soil. It is stated that this increase is caused by urea or urea type substrates covered by organic material [33]. Thus, it is determined that nutrient management and organic $\mathrm{N}$-fertilization increase the urease activity of the soil [34, 35]. Similarly, the sludge was found to increase urease activity in the soil. It can be stated that such an increase in enzyme activity was observed due to the high level of nitrogen forms, which are the substrates of the urease enzyme, in the sludge used in this study (total $\mathrm{N} 4.9 \%$ ). However, an inverse proportion was reported between urease activity and soil heavy metal coverage [36]. At this point, it is assumed that the chemical properties of the soil (lime $43 \%$ and $\mathrm{pH}$ 7.06) prevent the heavy metals in the sludge from increasing the soil solution.

\section{Alkaline Phosphatase Activity}

The course of alkaline phosphatase activity is similar to urease (Table 2). With SS6 (58.98 $\left.\mu \mathrm{g} \mathrm{PNP} \mathrm{g}^{-1} \mathrm{dw} \mathrm{h}^{-1}\right)$, the values measured in the first sampling time were found to be highest (Fig. 2). Phosphatase activity can be affected not only by $\mathrm{pH}$ and temperature values, but also by organic matter content, moisture and air of the soil. Due to these effects, the phosphotase activity in the soil varies according to the seasons and agronomic activities (fertilization, irrigation, etc.) [37]. In the case of organic wastes applied alone or in combination with chemical fertilizers, it was demonstrated that the physical and chemical soil properties improve together with the plant yield [8]. Unlike inorganic fertilizers, it is reported that organic fertilizers or regulators added to the soil increase phosphatase activity, so there is a parallel between soil organic matter amount and phosphatase activity. It is known that organic fertilizers, which are widely used to increase the soil organic matter, act as a substrate for the phosphatase enzyme, increasing the activity of this enzyme [38]. In this study, it was determined that the sludge was significantly increasing the alkaline phosphatase activity of the soil. In addition to the substrate amount and components of the material, the amount of organic matter and nutrient content of the material can be important in the emergence of the microbial stimulating effect of organic fertilizers in the soil [39]. In addition, phosphatase activity was reported to be closely related to soil $\mathrm{pH}$, total $\mathrm{N}$, organic $\mathrm{P}$, and clay content [40]. The test soil $\mathrm{pH}$ (7.06), total $\mathrm{N}$ amount $(0.13 \%)$ and texture (clay loam) with total phosphorus (16144 $\mathrm{mg} \mathrm{kg}^{-1}$ ) and organic matter content (74\%) of the sludge, is thought to be responsible for the increase in soil alkaline phosphatase activity. Similar results were reported in the field experiments which were carried out on the effect of organic fertilizer amendment in wheat and potato soil $[41,42]$.

\section{B-Glycosidase Activity}

Considering the average values of the applications depending on the sampling times, it was determined that SS6 (32.12 $\mu \mathrm{g}$ PNG $\mathrm{g}^{-1} \mathrm{dw} \mathrm{h}^{-1}$ ) and SS8 (31.98 $\mu \mathrm{g}$ PNG $\left.\mathrm{g}^{-1} \mathrm{dw} \mathrm{h}^{-1}\right)$ increased the $\beta$-glycosidase activity of the soil more than control and other applications (Table 2). On the other hand, in terms of sampling periods, as in other enzyme activities, it was determined that the $\beta$-glycosidase activity of the soil reached the highest levels in the first sampling time (Fig. 2). Carbonic compounds are the primary substances used 
by plants and microorganisms as an energy source in agricultural lands. Cellulose is one of the hardest to distinguish among carbon-containing compounds that participate in the vital activities of all living things and are responsible for providing them with energy. $\beta$-glucosidase, one of the enzymes active in the soil ecosystem, is the limiting enzyme in microbial separation of cellulose into glucose [43]. The activity of $\beta$-glycosidase depends on the quality and quantity of harvest residues remaining in the soil and the types and amounts of organic and inorganic fertilizers given to the soil, soil reaction and temperature, seizure and cultivation. By measuring the activity of this enzyme, important information can be obtained about the biological efficiency of the soil [44]. In this study, it was determined that the sludge has increased the $\beta$-glycosidase activity of the soil. This suggests that the sludge is both a source of nutrients and energy for heterotrophic microorganisms, similar to many organic fertilizers, and has a stimulating effect on microbial activity. Indeed, it was reported that soil $\beta$-glycosidase activity is promoted by various organic materials and organic fertilizer applications [45]. On the other hand, it is known that $\beta$-glucosidase activity is inhibited by the accumulation of heavy metals such as $\mathrm{Cu}$ and $\mathrm{Cd}$ in the soil [46]. However, this has not been the case here. In addition to the fact that the heavy metal coverage of the sludge used is below the international limit values, this situation is thought to occur due to soil lime content (43\%) and $\mathrm{pH}(7.06)$.

\section{Number of Bacteria}

Considering the average values of the applications depending on the sampling times, it was found that the soil increases the number of bacteria of SS6 and SS8 $\left(2.3 \times 10^{6} \mathrm{cfu}^{-1} \mathrm{dw}\right.$; for both) compared to control and all other applications (Table 2). In addition, it was determined that the number of bacteria of the soil reached the highest levels in the second sampling time (Fig. 2). Microorganisms need nutrient and energy to survive in the soil. The main nutrient and energy source of microorganisms in the soil is organic matter. Organic fertilizers or organic materials, which constitute the organic matter source of agricultural soils, provide suitable conditions for the reproduction of beneficial bacteria in the soil by increasing the amount of humus and colloidal surfaces in the soil [47].

Soil bacteria, are important elements of soil fertility as they take an active role in the cycle of critical nutrients such as nitrogen, phosphorus and carbon etc. [48]. One of the important parameters examined in this perspective is the presence of bacteria in the soil. It was determined that the applications increase the total number of heterotrophic aerobic mesophilic bacteria in the soil. At this point, it is highly probable that the sludge applied to the soil is rich in both microbial population and diversity. As mentioned earlier, the sludge used in the study is a very rich material especially by organic matter $(74 \%)$. Thus, it is thought that many and diverse microorganisms (especially bacteria) are added to the soil and the microorganisms existing in the soil are stimulated. Close results were reported for the effect of organic fertilization and sewage sludge biochar amendment on agricultural soil $[49,50]$. On the other hand, in a study conducted by Tamilselvi et al. [51], it was determined that microbial presence and enzyme activities in the soil in maize increased more in the growth season when the plant developed vegetative parts. In this study, it was determined that in the early period when the vegetative component of the maize developed, the enzyme activities and the number of bacteria increased in general. Thus, organic wastes applied to the soil increase bacterial diversity by enriching organic matter and prevent soil pollution by reducing the need for chemical fertilizers. Therefore, organic wastes are economical and widely effective organic fertilization materials, and their use should be expanded to maintain soil fertility [2].

\section{Conclusions}

Within the scope of the study, the effects of the sewage sludge on soil microbial dynamics were studied in a field in which maize was cultivated. According to the results obtained; it is clear that the sludge applications on soil enzyme activities and the number of bacteria have a stimulating effect. In other words, depending on the time-bound change factor, the effect of sludge applications on soil nitrification, urease, alkaline phosphatase, $\beta$-glycosidase activities and the number of bacteria was found to be positive. Despite the fact that the sludge application has positive effects on soil microbial dynamics, the risks that may occur in the long term (heavy metal accumulation in the soil, groundwater contamination etc.) should not be ignored. However, it can be stated that applying the material to a calcareous soil can significantly reduce risk factors (especially heavy metal accumulation). In addition, this material is thought to have the potential for an alternative soil conditioner to improve soil biological properties and thus maintain soil fertility. As a result, in order to improve the possibilities of the sewage sludge in vegetative production, it will be useful to carry out comprehensive studies in which different factors such as plant and soil type, production model, growth season and climate differ.

\section{Acknowledgements}

This study was financially supported by the Scientific Research Projects Coordination Unit of Akdeniz University (Project no. FYL-2017-2688). 


\section{Conflict of Interest}

The authors declare no conflict of interest.

\section{References}

1. ORMAN S., OK H., KAPLAN M. Application of sewage sludge for growing alfalfa, its effects on the macromicronutrient concentration, heavy metal accumulation, and translocation. Ekoloji, 23 (90), 10, 2014.

2. BÖRJESSON G., KATTERER T. Soil fertility effects of repeated application of sewage sludge in two 30-year-old field experiments. Nutrient Cycling in Agroecosystems, 112, 369, 2018

3. ORMAN S, OK H, FAHAD M, OZGUR A. Stabilize ve kurutulmuş evsel arıtma çamurundan humik asit eldesi ve çim (Lolium Perenne L.) yetiştiriciliğinde kullanımı. Mediterranean Agricultural Sciences, 33 (3), 411, 2020 [In Turkish].

4. OK H., ORMAN S. Nutrient element and heavy metal concentration of ryegrass (Lolium perenne L.) growing in calcareous soils amended with sewage sludge. Fresenius Environmental Bulletin, 27 (6), 4532, 2018.

5. VIERIA R.F., PAZIANOTTO R.A.A. Microbial activities in soil cultivated with corn and amended with sewage sludge. SpringerPlus, 5 (1), 1844, 2016.

6. PETERSON M.E., CURTIN D., THOMAS S., CLOUGH T.J., MEENKEN E.D. Denitrification in vadose zone material amended with dissolved organic matter from topsoil and subsoil. Soil Biology and Biochemistry, 61, 96, 2013.

7. SONG Y., ZHANG X., MA B., CHANG S.X. Biochar addition affected the dynamics of ammonia oxidizers and nitridication in microcosms of a coastal alkaline soil. Biology and Fertility of Soils, 5, 321, 2014.

8. URRA J., ALKORTA I., LANZEN A., MIJANGOS I., GARBISU C. The application of fresh and composted horse and chicken manure affects soil quality, microbial composition and antibiotic resistance. Applied Soil Ecology, 135, 73, 2019.

9. KACAR B. Chemical Analysis of Plant and Soil. Ankara University Agriculture Faculty Press, Ankara, 3, 1995 [In Turkish].

10. JACKSON M.L. Soil chemical analysis. New Delhi: Prentice Hall of India Private Limited, 1967.

11. KACAR B., INAL A. Plant Analysis. Nobel Press, Ankara, 1241, 2008 [In Turkish].

12. U.S. EPA. "Method 3051A (SW-846): Microwave Assisted Acid Digestion of Sediments, Sludges, and Oils," Revision 1. Washington, DC, 2007.

13. BOUYOUCOS G.J. A recalibration of hydrometer method for making mechanical analysis of soils. Agronomy Journal, 43, 434, 1951.

14. CAGLAR K.O. Soil Science. Ankara University Agriculture Faculty Press, Ankara, 10, 1949 [In Turkish].

15. BLACK C.A. Methods of soil analysis. Part 2. Wilconsin, USA: American Society of Agronomy Inc., Publisher Madisson, 1965.

16. SCHINNER F., OHLINGER R., KANDELER E., MARGESIN R. Assay of nitrification (shorth-term estimations). In: Methods in Appilied Soil Microbiology and Biochemistry, Alef K., Nannipieri P. (Eds), Academic Press INC. San Diego, 241, 1995.
17. SCHINNER F., OHLINGER R., KANDELER E., MARGESIN R. Assay of dissimilatory nitrate reductase activity. In: Methods in Applied Soil Microbiology and Biochemistry, Alef K., Nannipieri P. (Eds), Academic Press INC. San Diego, 283, 1991.

18. HOFFMAN G., TEICHER K. A colorimetric method to determine the urease activity in soil. Journal of Plant Nutrition and Soil Science, 95, 55, 1961 [In German].

19. TABATABAI M.A., BREMMER J.M. Use of p-nitrophely phosphate for assay of soil phosphatase activity. Soil Biology and Biochemistry, 1, 301, 1969.

20. EIVAZI F., TABATABI M.A. Assay of the $\beta$-glucosidase activity. In: Methods in applied soil microbiology and biochemistry, Alef K., Nannipieri P. (Eds), Academic Press INC., San Diego, 350, 1988.

21. PARKINSON D., GRAY T.R.C., WILLIAMS S.T. Methods for studying the ecology of soil microorganisms. International Biological Programme Handbook 19. Blackwell Scientific Publications, Oxford, 1971.

22. SPSS (version 17.0). Chicago, USA: IBM, 2008.

23. ZHONG L., DU R., DING K., KANG X., LI F.Y., BOWATTE S., HOOGENDOORN C.J., WANG Y., RUI Y., JIANG L., WANG S. Effects of grazing on $\mathrm{N}_{2} \mathrm{O}$ production potential and abundance of nitrifying and denitrifying microbial communities in meadowsteppe grassland in northern China. Soil Biology and Biochemistry, 69, 1, 2014.

24. WANG J., ZHANG L., LU Q., RAZA W., HUANG Q., SHEN Q. Ammonia oxidizer abundance in paddy soil profile with different fertilizer regimes. Applied Soil Ecology, 84, 38, 2014.

25. STRAUSS S.L., REARDON C.L., MAZZOLA M. The response of ammonia-oxidizer activity and community structure to fertilizer amendment of orchard soils. Soil Biology and Biochemistry, 68, 410, 2014.

26. TSIKNIA M., TZANAKAKIS V.A., OIKONOMIDIS D., PARANYCHIANAKIS N.V., NIKOLAIDIS N.P. Effects of olive mill wastewater on soil carbon and nitrogen cycling. Applied Microbiology and Biotechnology, 98, 2739, 2014.

27. QIN S., YUAN H., DONG W., HU C., OENEMA O., ZHANG Y. Relationship between soil properties and the bias of $\mathrm{N}_{2} \mathrm{O}$ reduction by acetylene inhibition technique for analyzing soil denitrification potential. Soil Biology and Biochemistry, 66, 182, 2013.

28. PETERSON M.E., CURTIN D., THOMAS S., CLOUGH T.J., MEENKEN E.D. Denitrification in vadose zone material amended with dissolved organic matter from topsoil and subsoil. Soil Biology and Biochemistry, 61, 96, 2013.

29. SMITH K.A. Changing views of nitrous oxide emissions from agricultural soil: key controlling processes and assessment at different spatial scales. European Journal of Soil Science, 68 (2), 137, 2017.

30. ABED R.M.M., LAM P., BEER D., STIEF P. High rates of denitrification and nitrous oxide emission in arid biological soil crusts from the Sultanate of Oman. The ISME Journal, 7, 1862, 2013.

31. LI J., LIANG L.N., LI X., YANG H.F. Effects of compost amendment on soil chemical and biological properties in greenhouse soil. I.International Symposium on Organic Matter Management and Compost Use in Horticulture Book Series: Acta Horticulturae, 1018, 195, 2014.

32. RAIESI F., BEHESHTI A. Soil specific enzyme activity shows more clearly soil responses to paddy rice cultivation 
than absolute enzyme activity in primary forests of northwest Iran. Applied Soil Ecology, 75, 63, 2014.

33. JIANG X., LIU W., LIU Q., JIA Z., WRIGHT A.L., CAO Z. Soil N mineralization, nitrification and dynamic changes in abundance of ammonia-oxidizing bacteria and archaea along a 2000 year chronosequence of rice cultivation. Plant Soil, 365, 59, 2013.

34. CHINNADURAI C., GOPALASWAMY G., BALACHANDAR D. Long term effects of nutrient management regimes on abundance of bacterial genes and soil biochemical processes for fertility sustainability in a semi-arid tropical Alfisol. Geoderma, 232, 563, 2014.

35. HARTMANN A.A., BARNARD R.L., MARHAN S., NIKLAUS P.A. Effects of drought and N-fertilization on N cycling in two grassland soils. Oecologia, 171, 705, 2013.

36. PAJAK M., BLONSKA E., SZOSTAK M., GASIOREK M., PIETRZYKOWSKI M., URBAN O., DERBIS P. Restoration of Vegetation in Relation to Soil Properties of Spoil Heap Heavily Contaminated with Heavy Metals. Water, Air, and Soil Pollution, 229 (12), 392, 2018.

37. LEMANOWICZ J. Dynamics of phosphorus content and the activity of phosphatase in forest soil in the sustained nitrogen compounds emissions zone. Environmental Science and Pollution Research, 25, 33773, 2018.

38. PATEL D.P., DAS A., MANOJ KUMAR G., MUNDA C., NGACHAN S.V., RAMKRUSHNA G.I., LAYEK J., PONGLA N., BURAGOHAIN J., SOMIREDDY U. Continuous application of organic amendments enhances soil health, produce quality and system productivity of vegetable-based cropping systems in subtropical Eastern Himalayas. Experimental Agriculture, 51, 85, 2015.

39. SCOTTI R., BONANOMI G., SCELZA R., ZOINA A., RAO M.A. Organic amendments as sustainable tool to recovery fertility in intensive agricultural systems. Journal of Soil Science and Plant Nutrition, 15 (2), 333, 2015.

40. OLIVEIRA S.M., FERREIRA A.S. Change in soil microbial and enzyme activities in response to the addition of rock-phosphate-enriched compost. Communications in Soil Science and Plant Analysis, 45 (21), 2794, 2014.

41. HU W., JIAO Z., WU F., LIU Y., DONG M., MA X., FAN T., AN L., FENG H. Long-term effects of fertilizer on soil enzymatic activity of wheat field soil in Loess Plateau, China. Ecotoxicology, 23 (10), 2069, 2014.

42. NINH H.T., GRANDY A.S., WICKINGS K., SNAPP S., KIRK W., HAO J. Organic amendments effects on potato productivity and quality are releated to soil microbial activity. Plant and Soil, 386, 223, 2015.

43. AHMED A., NASIM F., BATOOL K., BIBI A. Microbial $\beta$-Glucosidase: Sources, Production and Applications. Journal of Applied and Environmental Microbiology, 5 (1), 31, 2017.

44. TIWARI R., DWIVEDI B.S., SHARMA Y.M., SHARMA A., DWIVEDI A.K. Activities of $\beta$-glucosidase, Phosphatase and Dehydrogenase as Soil Quality Indicators: A Review. International Journal of Current Microbiology and Applied Sciences, 8 (6), 834, 2019.

45. SIMON T., CZAKO A. Influence of long-term application of organic and inorganic fertilizers on soil properties. Plant Soil and Environment, 60 (7), 314, 2014.

46. DINDAR E., TOPAÇ SAĞBAN F.O., BAŞKAYA H.S. Ham petrol ve atık yağ ile kirlenmiş topraklarda arıtma çamuru uygulamasının enzim aktivitelerine etkisi. Uludağ University Journal of The Faculty of Engineering, 22 (1), 81, 2017 [In Turkish].

47. ABED R.M.M., BEER D., STIEF P. Functional-structural analysis of nitrogen-cycle bacteria in a hypersaline mat from the omani desert. Geomicrobiology Journal, 32 (2), 119, 2015.

48. YACOBY R., PEUKERT M., SUCCURRO A., KOPRIVOVA A., KOPRIVA S. The Role of Soil Microorganisms in Plant Mineral Nutrition - Current Knowledge and Future Directions. Frontiers in Plant Science, 8, 1617, 2017.

49. DEBNATH S., PATRA A.K., AHMED N., KUMAR S., DWIVEDI B.S. Assessment of microbial biomass and enzyme activities in soil under temperate fruit crops in north western himalayan region. Journal of Soil Science and Plant Nutrition, 15 (4), 848, 2015.

50. YOU J., SUN L., LIU X., XU Q. Effects of sewage sludge biochar on soil characteristics and crop yield in loamy sand soil. Polish Journal of Environmental Studies, 28 (4), 2973, 2019.

51. TAMILSELVI S.M., CHINNADURAI C., ILAMURUGU K., ARULMOZHISELVAN K., BALACHANDAR D. Effect of long-term nutrient management on biological and biochemical properties of semi-arid tropical Alfisol during maize crop development stages. Ecological Indicators, 48, 76, 2015. 